\section{GREEN-TAILED TOWHEE IN NORTH DAKOTA}

by B. J. Rose, Bismarck, North Dakota

On May 13, 1965, a male Greentailed Towhee (Chlorura chlorura) was found in Bismarck, North Dakota. This individual had apparently flown into a window and was found in a window well on north Third Street. Mr. Donald Feimer brought the injured bird to my home on the above date. When first discovered the towhee was unconscious. My wife cared for it until May 21, when it was banded by Robert Randall and released on the State Capito] Grounds. Upon release it took to the wing with no indication of injury. This appears to be the first record of this species in North Dakota.

During the period of confinement in a bird cage, the towhee was fed a wild bird seed mixture and bread. We kept the cage covered with a cloth to prevent the bird from attempting to escape. When the cloth was in place the bird was calm and could be heard scratching in the bottom of the cage and feeding, but when the cover was removed it became very nervous and excited.

The Green-tailed Towhee breeds from southwestern and central Oregon, southeastern Washington, southern Idaho, southwestern Montana and northwestern, central and southeastern Wyoming, south through the interior mountains to southern California, southern Nevada, central Arizona and southern New Mexico. In migration it reaches western Kansas and western Oklahoma. It has been recorded as casual north to Saskatchewan (Dollard, Tregarva) and east to Massachusetts, New Jersey, Virginia, South Carolina and Louisiana (A.O.V. Check-list, 5th Edition).

Editor's Note: The Saskatchewan records are as follows: a male collected on June 6, 1929 at Tregarva and another seen near Tregarva on June 28, 1935 (N. Clark); a female collected at Dollard, May 18, 1944

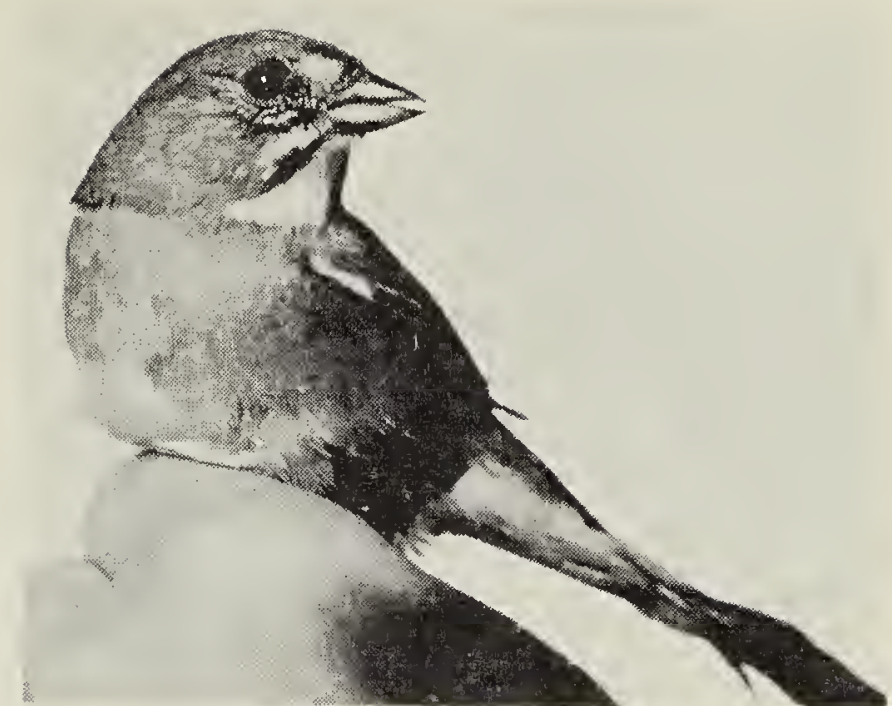

Conversion from color by B. J. Rose Green-tailed Towhee, May, 1965

(C. F. Holmes). Dollard is in the extreme southwest, Tregarva is near Regina.

\section{MOCKINGBIRD AT BUFFALO POUND LAKE}

by the late Harley Jenner, Regina

On the afternoon of June 20, 1965 I was visiting at Buffalo Pound Lake. Near the west end of the picnic grounds I heard a bird song that I had never heard before, and I walked toward it with the binoculars. I got within about 20 yards before the bird flew. It was robin size, light gray in colour, and flew with a straight nonundulating flight. The song was loud and rich; clearly not a Catbird or Brown Thrasher, but with overtones of each, though much richer and fuller. I feel quite certain that this was a Mockingbird - the first I have seen or heard.

\section{PILEATED WOODPECKER SURVEY}

Spencer G. Sealy reports that he is interested in documenting the distribution and status of the Pileated Woodpecker in Saskatchewan. Anyone with information or records pertaining to this magnificent woodpecker is urged to correspond with Sealy at Box 175, Battleford, Saskatchewan. 